\title{
Pioneer in Quality of Urban Life Research: Robert W. Marans
}

\section{Robert Marans ${ }^{1}$}

Published online: 28 July 2021

(c) The International Society for Quality-of-Life Studies (ISQOLS) and Springer Nature B.V. 2021

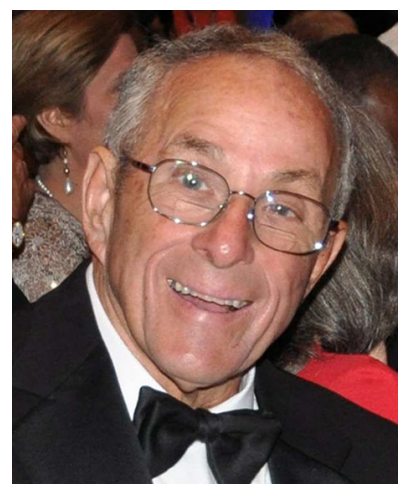

The path leading to my career as a researcher exploring the influence of built and natural environments on quality of urban life has been anything but direct. Numerous external circumstances for which I had little or no control often determined its direction.

As a young boy growing up in Detroit, Michigan, I liked to draw. WW2 vintage airplanes and buildings were my favorite subjects. In high school, my career choices were aeronautical engineering or architecture. I chose the latter and enrolled at the University of Michigan (U-M) to pursue an architectural degree.

Following graduation and wanting to remain in Detroit, I began my job search at a bad time. Detroit was in the midst of a recession. Building construction was at a standstill, and consequently, architectural firms were laying off people and certainly not hiring young aspiring graduates. However, the Detroit planning department was, and after passing a civil service examination, I began working as a junior architectural engineer planning urban renewal projects within Detroit's inner city. I intended

Robert Marans

marans@umich.edu

1 Institute for Social Research, University of Michigan, 426 Thompson St., Ann Arbor, MI 48106, USA 
to work in the planning department until the economy improved and then pursue an architectural career.

During the first months of my employment with the city, Wayne State University launched a new graduate program in urban planning. The program targeted professionals working in the Detroit region who lacked formal planning credentials. I was a perfect candidate. So why not? I enrolled in one evening course and then several others. Four years had passed and before I knew it, I had earned a planning degree and had considerable practical experience. Moreover, through my graduate courses and my work in urban renewal, I realized that design and planning had significant impacts on people's lives.

After graduation, I joined a prestigious consulting firm in Rhode Island, where I broadened my experience through master planning in both small towns and large regions. As part of this work, I had to deal with planning boards and diverse groups of citizens. During this period, I came across the inspirational writings of Artur Glikson, an Israeli architect. Glikson's words and his professional work were guided in part by the conceptual thinking of Patrick Geddes, the early twentieth-century Scottish sociologist, geographer, and town planner. On impulse, I wrote to Glikson, and after several months of correspondence, he invited me to join his small firm. The timing was prescient; my Rhode Island consulting firm had declared bankruptcy.

Soon afterwards, I moved my young family from Providence to Tel Aviv to begin my new job. I became part of an interdisciplinary team responsible for planning, designing, and building an experimental neighborhood in one of Israel's new towns. The neighborhood was experimental in its efforts to mix new immigrants from Europe and North Africa with veteran Israelis. The planned integration was guided by the pioneering research of Judith Shuval, a Harvard trained sociologist, a member of Glikson's team, and a researcher at Louis Guttman's Israel Institute of Applied Social Research. One of Shuval's responsibilities was to evaluate the experiment in terms of social relations and resident satisfaction. I was assigned to work with Shuval, who introduced me to the intricacies of social surveys and evaluation research. After nearly two years of working with Glikson and Shuval, funding for the experimental neighborhood was dramatically reduced impacting Glikson's staff including me. It was time to return to the States.

After moving back to the Detroit area, I joined a newly established regional planning agency. My responsibilities included inventorying the region's natural and visual resources and, because of my experiences with Shuval, to work with John Lansing from U-M's Institute for Social Research (ISR). Lansing was hired to design and conduct a living patterns and attitudes survey of Detroit area residents. Lansing was an economist whose research focused on travel behavior and residential mobility.

Concurrent with my job with the regional planning agency, I was invited to teach part-time at several universities. I had much to share about my work in the US and internationally. I enjoyed the teaching and began to think about a career change. I soon realized that a doctoral degree would be necessary if an academic life was in my future. I shared these thoughts with Lansing, who suggested that if I were to attend U-M, I could work with him while pursuing my $\mathrm{PhD}$. So, in summer 1968, I joined the first cohort of U-M's new interdisciplinary doctoral 
program in planning and began working part-time at ISR. Lansing had just received a large grant to study travel behavior and other aspects of life in new towns, including Columbia, Maryland and Reston, Virginia. He needed help and viewed my planning background as applicable. He also hired a third-year sociology graduate student with substantial coursework and survey research experience. Robert Zehner and I shared an office for more than two years and used the data from the study of the new town for our respective dissertations. Mine dealt with the environment and psychological determinants of recreation behavior, while Zehner's dissertation addressed the topic of neighborhood satisfaction. The intense interaction with Zehner and Lansing during this period was instrumental to my development as a researcher. It was also when I began thinking about environmental factors that might contribute to health and well-being.

Another fortuitous event that shaped the direction of my career was the sudden death of Lansing, who also chaired my dissertation committee. This occurred just before completing my manuscript. I was fortunate to have another committee member (Frank Andrews) guide me through the final stages of my doctoral work. About the same time, Angus Campbell, ISR's director, began to show interest in my research. It was a period when both Campbell and Andrews were launching their pioneering work on subjective well-being and quality of life.

Soon after defending my dissertation, another committee member asked me to join him in writing a proposal to evaluate a new federally sponsored environmental program. Our proposal was accepted, and I had guaranteed continued employment at ISR for three additional years. Besides my research, I began teaching research methods in U-M's College of Architecture and Urban Planning. I received tenure in 1974 , in part because of my success in teaching and my publications record.

My work with Campbell began by examining the residential environment visà-vis QOL as part of his seminal study with Converse and Rodgers (Marans \& Rodgers, 1976). In the late 1970s, Rodgers and I replicated that work in the Detroit region. Around the same time, I directed an NSF-funded study on QOL in a nonmetropolitan area of northern Michigan (Marans \& Wellman, 1978). This allowed me to compare the views of northern Michigan residents with those of Detroit area residents and respondents from the Campbell et al. national survey.

In 2001, I again directed a QOL study in the Detroit area to see how life in the region changed over time (Marans \& Kweon, 2011; Marans, 2003, 2015). I planned to replicate that work throughout the early part of the twenty-first century with the hopes that others would continue it following my retirement. Unfortunately, these plans did not materialize. My other hope was that similar work would take place in other metropolitan areas around the world. It was. There were similar QOL studies conducted in Southeast Queensland in Australia, Istanbul, and Famagusta, Cyprus. These studies and other research focusing on QOL are discussed in Marans and Stimson (2011). They will also be summarized in a forthcoming handbook dealing with QOL from a spatial and place perspective (Marans et al., forthcoming).

Over the years, I was recognized for my scholarship and academic contributions. I was a Social Science Research Council Pre-doctoral Fellow (1970-71), Fulbright Scholar (1977), recipient of a Design Recognition Award from the National 
Endowment for the Arts (1983), a Career Award from the Environmental Design Research Association (2012), and elected as a Fellow of the American Institute of Certified Planners (2014).

I formally retired in 2004 but have remained active at ISR since that time.

\section{References}

Marans, R. W., \& Rodgers, W. (1976). The Residential Environment. In A. Campbell, P. Converse, \& W. Rodgers (Eds.), The Quality of American Life: Perceptions, Evaluations and Satisfactions (pp. 217-261). Russell Sage Foundation.

Marans, R. W., \& Wellman, J. D. (1978). The Quality of Non-metropolitan Living: Evaluations, Behaviors and Expectations of Northern Michigan Residents. ISR-U-M.

Marans, R. W. (2003). Understanding Environmental Quality through Quality of Life Studies: The 2001 DAS and Its Use of Subjective and Objective Indicators. Landscape and Urban Planning, 65, 73-83.

Marans, R. W., \& Stimson, R. (Eds.). (2011). Investigating Quality of Urban Life: Theory, Methods, and Empirical Research. Springer.

Marans, R. W., \& Kweon, B.-S. (2011). The Quality of Life in Metro Detroit at the Beginning of the Millennium. In R. W. Marans \& R. Stimson (Eds.), Investigating Quality of Urban Life: Theory, Methods, and Empirical Research. Springer.

Marans, R. W. (2015). Quality of Urban Life \& Environmental Sustainability Studies: Future Linkage Opportunities. Habitat International, 45, 47-52.

Marans, R.W., R. Stimson, \& N. Webster (eds.) (Forthcoming). Handbook of Quality of Life Research: Space and Place Perspectives. Edward Elgar.

Publisher's Note Springer Nature remains neutral with regard to jurisdictional claims in published maps and institutional affiliations. 